\title{
FREQUENCY OF DYSLIPIDEMIA IN PATIENTS UNDERGOING MAINTENANCE HEMODIALYSIS AT BAHAWAL VICTORIA HOSPITAL, BAHAWALPUR.
}

1. MBBS, FCPS (Medicine), FCPS (Nephrology)

Assistant Professor Nephrology QAMC/BVH, Bahawalpur.

2. MBBS, FCPS (Medicine) Senior Registrar Medicine QAMC/BVH, Bahawalpur.

3. MBBS, FCPS (Medicine) Assistant Professor Medicine QAMC/BVH, Bahawalpur.

4. MBBS, FCPS (Medicine) Assistant Professor Medicine QAMC/BVH, Bahawalpur.

5. MBBS

Medical Officer Nephrology QAMC/BVH, Bahawalpur.

6. MBBS

PGR Nephrology

QAMC/BVH, Bahawalpur.

Correspondence Address:

Dr. Raheel Khan

Department of Medicine

QAMC/BVH, Bahawalpur.

x raheel@yahoo.com

Article received on:

25/07/2019

Accepted for publication:

$19 / 12 / 2019$

\section{INTRODUCTION}

Dyslipidemia has high prevalence in patients undergoing hemodialysis. It is defined as triad of high TGs, elevated vLDL and reduced HDL. ${ }^{1}$ Dyslipidemia is one of the pathology of metabolic syndrome which is associated with accelerated atherosclerosis. Accelerated atherosclerosis causes increase rate of cardiovascular events in suffering patients and increase in mortality rate. ${ }^{2}$ Chronic kidney disease is high risk equivalent to coronary heart disease. ${ }^{3}$ Cardiovascular events have high incidence among the patients undergoing hemodialysis. ${ }^{4}$ It is the leading cause of death among the hemodialysis patients. ${ }^{5,6}$ The risk factors of cardiovascular events are more prevalent in hemodialysis patients than in general population of same age and gender. There is great impact of reducing these risk factors to decrease the burden of coronary heart disease. ${ }^{7}$ According to K/DOQI guidelines treatment should be considered in patients of hemodialysis having dyslipidemia and cardiovascular events. ${ }^{8}$

The study was planned to assess lipid profile of hemodialysis patients and identify the patients at risk of cardiovascular events.

\section{MATERIAL \& METHODS}

The study was conducted at Dialysis Unit, Bahawal Victoria Hospital, Bahawalpur January to May 2019. After approval from Institutional ethical committee and informed consent from the patients 220 patients of both gender and undergoing hemodialysis twice per week for last 3 months were included in the study. Patients who refused to give consent and were already taking treatment for dyslipidemia were excluded from the study. The data was collected on predesigned pre-tested questionnaire. Blood samples were taken pre-dialysis and were sent 
to QMC, Pathology Lab for processing on same day.

Data was analyzed using spss v.23.0. Mean and SD were calculated for quantitative variables. Frequency and percentages were calculated for qualitative variables. Effect modifiers were controlled using stratification. Post-stratification chi square test was applied taking $p$-value $<0.05$.

\section{RESULTS}

Total 220 patients were included in the study. $66.8 \%$ of them were male. $16(7.3 \%)$ were smokers. Renal stone disease (22.3\%) was most common cause of CKD followed by Diabetes Mellitus (21.4\%). Out of 220 09(4.1\%) were HBsAg positive, $110(50 \%)$ were Anti-HCV positive and $101(45.9 \%)$ were negative patients. Patients 28 (12.7\%), 59 (26.8), 158(71.8\%) had abnormal Sr. Cholesterol, Sr. TGs \& Sr. HDL respectively.

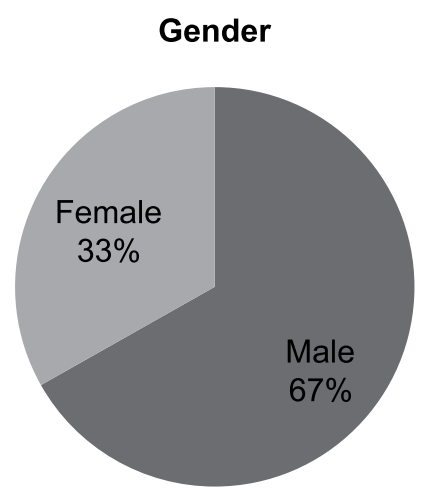

Figure-1. Gender of the patients.

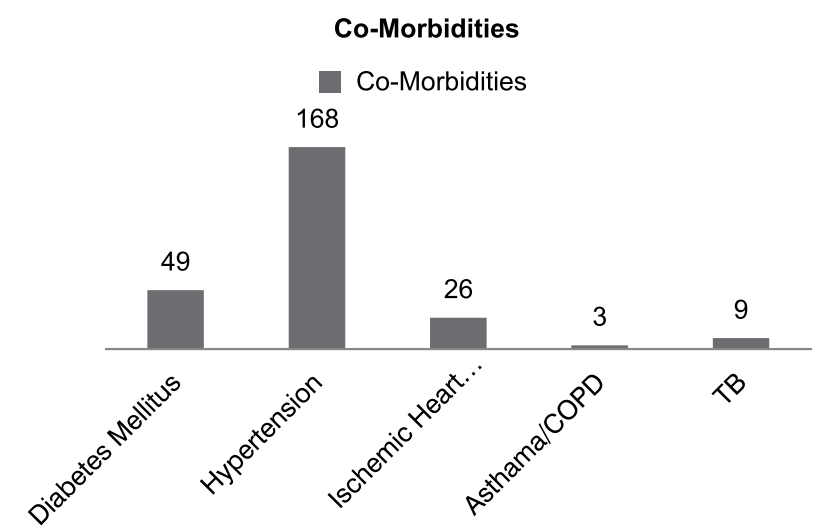

Figure-3. Co-morbidities of patients.
Dyslipidemia was found in $176(80 \%)$ of the patients. No statistical significance was found in stratification of gender, age groups, cause of renal failure, smoking, co-morbidities (Diabetes mellitus, Hypertension, Ischemic Heart Disease, Obstructive airway disease, Tuberculosis, Viral markers status).

\begin{tabular}{|c|c|c|}
\hline Variable & Mean & SD \\
\hline Age & 42.16 (years) & 14.921 \\
\hline Duration of Hemodialysis & 27.12 (months) & 25.859 \\
\hline Sr. Cholesterol (Total) & $155.51(\mathrm{mg} / \mathrm{dl})$ & 37.722 \\
\hline Sr. Triglycerides & $135.54(\mathrm{mg} / \mathrm{dl})$ & 89.27 \\
\hline Sr. HDL & 35.22 (mg/dl) & 7.776 \\
\hline \multicolumn{3}{|c|}{ Table-I. Descriptive Statistics. } \\
\hline Age Groups & Frequency & Percentage \\
\hline Less than 26 years & 36 & 16.4 \\
\hline 26 to 50 years & 118 & 53.6 \\
\hline Above 50 Years & 66 & 30.0 \\
\hline
\end{tabular}

Cause of CKD

Cause of CKD

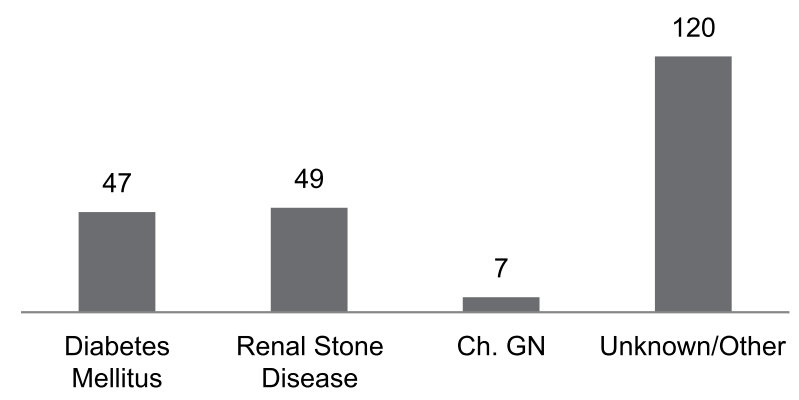

Figure-2. Cause of CKD.

Hepatitis Status

HbsAg $\square$ Anti-HCV $\square$ Negative

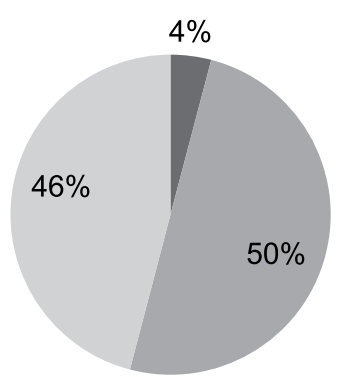

Figure-4. Hepatitis marker status of patients. 


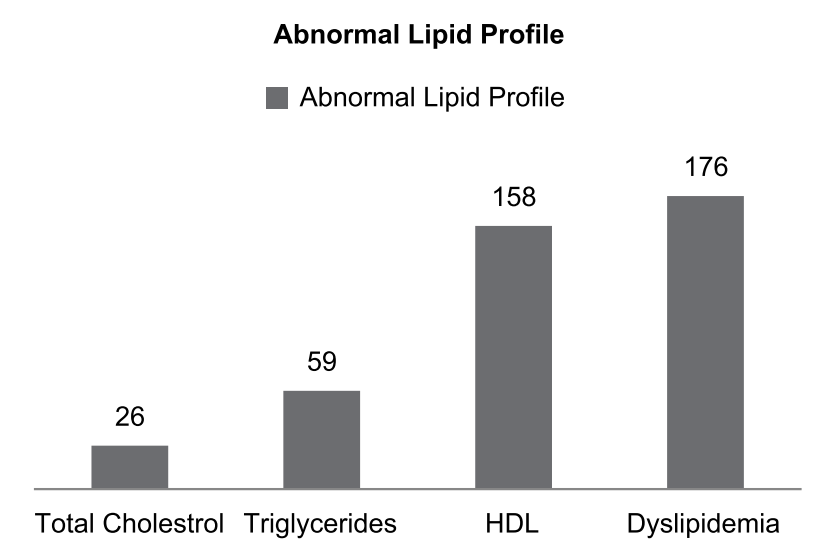

Figure-5. No. of patients having abnormal lipid profile.

\begin{tabular}{|l|c|c|}
\hline \multicolumn{1}{|c|}{ Duration of Dialysis } & Frequency & Percentage \\
\hline Up to one year & 74 & 33.6 \\
\hline One to two years & 65 & 29.5 \\
\hline More than two years & 81 & 36.8 \\
\hline \multicolumn{2}{|c|}{ Table-III. Duration of Dialysis. } \\
\hline
\end{tabular}

\section{DISCUSSION}

The study was used to assess the frequency of dyslipidemia in patients undergoing hemodialysis so that measures can be adopted at the centre to decrease the incidence of cardio vascular events among these patients.

The serum total cholesterol mean was in normal range in the patients although $12.7 \%$ of patient's higher serum total cholesterol levels. KalantarZadeh et al observed that serum total cholesterol was low in hemodialysis patients as compared to normal healthy population. This was attributed to low BMI in hemodialysis patients. Most of the patients of hemodialysis have mal nutrition due to uremia. ${ }^{9}$

The most common lipid abnormality in our patients was low HDL-c levels. Average HDL-c was $35.22+$ $7.77 \mathrm{mg} / \mathrm{dl}$ which is below than normal and $71.8 \%$ of patients had this abnormality. It was in contrast to $51 \%$ and $33 \%$ of Pennell $P$ et al and CHOICE study respectively. ${ }^{1,10}$ The low levels of HDL-C are associated with risk of coronary arteries as well as peripheral arterial disease. ${ }^{10}$ Chronic kidney disease is itself a cause of low HDL-c and it is also associated with weight loss. ${ }^{11}$
In our study $26.8 \%$ of patients had high serum triglycerides levels. The CHOICE study showed that this number was $36 \%$ and Pennell et al found it to be $52 \% .^{1,9}$ The level of triglycerides is highly dependent on non-fasting state of the patients. That is why it has high variability in different studies. $^{12}$

In different studies there was low levels of Sr. Cholesterol (Total), HDL-c \& TGs in female patients but in our study no statistical significance was found among both genders. This may be due to decrease in these levels after menopause secondary to decrease estrogen levels. ${ }^{13,14}$ Females have early age of menopause than normal population in End Stage renal disease. ${ }^{15}$

Dyslipidemia has an inverse relationship to better survival rates. ${ }^{16}$ Dyslipidemia is associated with increase cardiovascular events and increase mortality among normal as well as hemodialysis patients. ${ }^{17}$ Both malnutrition and inflammation can lead to dyslipidemia in patients of chronic kidney disease and hemodialysis. ${ }^{18}$ There can be also deficiency of antioxidants and low immunity leading to decrease ability to remove endotoxins. ${ }^{19}$ The uremia and hemodialysis leads to oxidative stress, increase synthesis of complement fragments and cytokines and other pro-inflammatory factors leading to accelerated atherosclerosis. ${ }^{20}$

These issues can be dealt with multi-disciplinary approach including counseling of patients regarding health life style, daily activity, nutritional support and pharmacological therapy when indicated.

\section{CONCLUSION}

Dyslipidemia is highly prevalent among the patients of maintenance hemodialysis increasing the morbidity and mortality of patients. Malnutrition and inflammation being the cause of dyslipidemia and atherosclerosis. Multidisciplinary approach is required to deal with this issue.

\section{Limitation}

The study was limited because of non availability of LDL-c and non-HDL-c cholesterol assessment 
at the centre and non-fasting status of patients when blood samples were taken.

\section{Copyright@ 19 Dec, 2019.}

\section{REFERENCES}

1. Pennell P, Leclercq B, Delahunty MI, Walters BA. The utility of non-HDL in managing dyslipidemia of stage 5 chronic kidney diseases. Clin Nephrol 2006 Nov; 66(5):336-47.

2. Abrass CK. Lipid metabolism and renal disease. Contrib Nephrol. 2006; 151:106-21.

3. National Kidney Foundation. K/DOQI clinical practice guidelines for chronic kidney disease: Evaluation, classification, and stratification. Am J Kidney Dis. 2002; 39:S1-266.

4. Gowdak LH, Arantes RL, de Paula FJ, Krieger EM, De Lima JJ. Under use of American College of Cardiology/American heart association guidelines in hemodialysis patients. Ren Fail. 2007; 29(5):559-65.

5. Soubassi LP, Papadakis ED, Theodoropoulos IK, Poulos GD, Chaniotis D, Tsapakidis IP et al. Incidence and risk factors of coronary artery disease in patients on chronic hemodialysis. Int Artif Organs 2007 Mar; 30(3):253-7.

6. Al Wakeel JS, Mitwalli AH, Al Mohaya S, Abu-Aisha H, Tarif N, Malik GH, et al. Morbidity and mortality in ESRD patients on dialysis. Saudi J Kidney Dis Transpl. 2002 October-December; 13(4):473-7.

7. Muntner P, He J, Astor BC, Folsom AR, Coresh J. Traditional and nontraditional risk factors predict coronary heart disease in chronic kidney disease: Results from the atherosclerosis risk in communities study. J Am Soc Nephrol. 2005 Feb; 16(2):529-38.

8. National Kidney Foundation. K/DOQI clinical practice guidelines for managing dyslipidemias in chronic kidney disease. Am J Kidney Dis. 2003; 41(suppl 3):S1-S92.

9. Kalantar-Zadeh K, Kilpatrick RD, Kopple JD, Stringer WW. A matched comparison of serum lipids between hemodialysis patients and nondialysis morbid controls. Hemodial Int. 2005 Jul; 9(3):314-24.

10. Longenecker JC; Coresh J; Powe NR; Levey AS; Fink NE; Martin A et al. Traditional cardiovascular disease risk factors in dialysis patients compared with the general population: The CHOICE Study. J Am Soc Nephrol 2002 Jul;13(7):1918-27
11. Williamson MA, Snyder LM, Wallach JB. Wallach's interpretation of diagnostic tests. 9th ed. Wolters Kluwer/Lippincott Williams \& Wilkins Health: Philadelphia; 2011.

12. Miller M, Stone NJ, Ballantyne C, et al. Triglycerides and cardiovascular disease: A scientific statement from the American Heart Association. Circulation. 2011 May 24. 123(20):2292-333.

13. Caparević $Z$, Kostić $N$. The influence of age and the beginning of menopause on the lipid status, LDL oxidation, and CRP in healthy women. Srp Arh Celok Lek. 2007 May Jun; 135(5-6):280-5

14. Trémollières FA, Pouilles JM, Cauneille C, Ribot C. Coronary heart disease risk factors and menopause: a study in 1684 French women. Atherosclerosis. 1999 Feb; 142(2):415-23.

15. Jang C, Bell RJ, White VS, Lee PS, Dwyer KM, Kerr PG et al. Women's health issues in haemodialysis patients. Med J Aust. 2001 Sep 17; 175(6):298-301

16. Kilpatrick RD, McAllister CJ, Kovesdy CP, Derose SF, Kopple JD, Kalantar-Zadeh K. Association between serum lipids and survival in hemodialysis patients and impact of race. J Am Soc Nephrol. 2007 Jan; 18(1):293-303

17. Kalantar-Zadeh K. Recent advances in understanding the malnutrition-inflammation-cachexia syndrome in chronic kidney disease patients: What is next? Semin Dial. 2005 Sep Oct; 18(5):365-9

18. Kalantar-Zadeh K, Ikizler TA, Block G, Avram MM, Kopple JD. Malnutrition-inflammation complex syndrome in dialysis patients: causes and consequences. $\mathrm{Am} \mathrm{J}$ Kidney Dis. 2003 Nov; 42(5):864-81.

19. Deicher R, Ziai F, Bieglmayer C, Schillinger M, Horl $\mathrm{WH}$. Low total vitamin C plasma level is a risk factor for cardiovascular morbidity and mortality in hemodialysis patients. J Am Soc Nephrol 2005 Jun; 16(6):1811-8.

20. Bro S, Bentzon JF, Falk E, Andersen CB, Olgaard $\mathrm{K}$, Nielsen LB. Chronic renal failure accelerates atherogenesis in apolipoprotein E-deficient mice. J Am Soc Nephrol 2003 Oct; 14(10):2466-74. 


\section{AUTHORSHIP AND CONTRIBUTION DECLARATION}

\begin{tabular}{|c|l|l|}
\hline Sr. \# & Author(s) Full Name & \multicolumn{1}{|c|}{ Contribution to the paper } \\
\hline 1 & Suhail lqbal Malik & $\begin{array}{l}\text { Conception \& design, acquisition of data, } \\
\text { analysis \& interpretation of data, Drafting } \\
\text { the article, Revising it critically for important } \\
\text { intellectual content. } \\
\text { Conception \& design, acquisition of data, } \\
\text { analysis \& interpretation of data, Drafting } \\
\text { the article, Revising it critically for important } \\
\text { intellectual content. } \\
\text { Drafting the article, Revising it critically for } \\
\text { important intellectual content. } \\
\text { Drafting the article, Revising it critically for } \\
\text { important intellectual content. } \\
\text { Conception \& design, acquisition of data, } \\
\text { analysis \& interpretation of data, Drafting } \\
\text { the article, Revising it critically for important } \\
\text { intellectual content. } \\
\text { Conception \& design, acquisition of data, } \\
\text { analysis \& interpretation of data, Drafting } \\
\text { the article, Revising it critically for important } \\
\text { intellectual content. }\end{array}$ \\
\hline 5 & Raheel Khan & Sidra Maqbool \\
6 & Rashid Habib & Mohammad Akram
\end{tabular}

